\title{
Daily Light Integral Influences Rooting of Herbaceous Stem-tip Culinary Herb Cuttings
}

\author{
Annika E. Kohler and Roberto G. Lopez \\ Department of Horticulture, Michigan State University, East Lansing, MI \\ 48824
}

Additional index words. Mentha spicata, Origanum vulgare, propagation, Rosmarinus officinalis, Salvia officinalis, Thymus vulgaris, young plants

\begin{abstract}
Domestic production of culinary herbs continues to increase in the United States. Culinary herbs are primarily propagated by seed; however, some herbs have poor germination rates and slow growth. Thus, there are advantages of propagating herbs by vegetative stem-tip cuttings as they lead to true-to-type plants and a shortened production time. Previous research of ornamental young plants and finished culinary herbs have shown a reduction in rooting time and increases in plant quality with increases in the photosynthetic daily light integral (DLI). To our knowledge, little to no research has addressed how the DLI influences culinary herb liner quality. Therefore, the objectives of this study were to quantify morphological traits of five economically important culinary herbs when grown under DLIs ranging from 2.8 to $16.4 \mathrm{~mol} \cdot \mathrm{m}^{-2} \cdot \mathrm{d}^{-1}$. Stem-tip cuttings of Greek oregano (Origanum vulgare var. hirtum), rosemary 'Arp' (Rosmarinus officinalis), sage 'Extrakta' (Salvia officinalis), spearmint 'Spanish' (Mentha spicata), and thyme 'German Winter' (Thymus vulgaris) were excised from stock plants and rooted under no shade or aluminum shading of $36 \%, 56 \%$, or $76 \%$ to create a range of DLI treatments. After 9 days (spearmint) or 16 days (all other genera) of DLI treatments, the root, shoot, and total dry mass of all culinary herb liners generally increased by $105 \%$ to $449 \%, 52 \%$ to $142 \%$, and $82 \%$ to $170 \%$, respectively, as the DLI increased from 2.8 to $16.4 \mathrm{~mol} \cdot \mathrm{m}^{-2} \cdot \mathrm{d}^{-1}$ or genus-specific DLI optimums. Stem length of oregano, spearmint, and thyme decreased by $37 \%, 28 \%$, and $27 \%$, respectively, as the DLI increased from 2.8 to $16.4 \mathrm{~mol} \cdot \mathrm{m}^{-2} \cdot \mathrm{d}^{-1}$. However, stem length of rosemary and sage were unaffected by the DLI. The quality index of all genera was greatest at DLIs from 10.4 to $16.4 \mathrm{~mol} \cdot \mathrm{m}^{-2} \cdot \mathrm{d}^{-1}$. Furthermore, all culinary herbs grown under a DLI of $\leq 6 \mathrm{~mol} \cdot \mathrm{m}^{-2} \cdot \mathrm{d}^{-1}$ had low root and shoot dry mass accumulation; and oregano, spearmint, and thyme were generally taller. Therefore, DLIs between 10 to $12 \mathrm{~mol} \cdot \mathrm{m}^{-2} \cdot \mathrm{d}^{-1}$ should be maintained during culinary herb propagation, because a DLI $\geq 16 \mathrm{~mol} \cdot \mathrm{m}^{-2} \cdot \mathrm{d}^{-1}$ may be deleterious and energy inefficient if supplemental lighting use is increased.
\end{abstract}

The market demand for fresh, dried, and living culinary herbs has increased over the past decade. In 2019, the wholesale value of culinary herbs produced in the United States was $\$ 58.4$ million, a 16\% increase from 2009 (USDA, 2010, 2020). Furthermore, culinary

Received for publication 30 Sept. 2020. Accepted for publication 5 Jan. 2021.

Published online 18 February 2021.

This work was supported by Michigan State University AgBioResearch (including Project GREEEN GR19-019), the U.S. Department of Agriculture (USDA) National Institute of Food and Agriculture (Hatch project MICL02472), and The Fred C. Gloeckner Foundation. The use of trade names in this publication does not imply endorsement by Michigan State University of products named nor criticism of similar ones not mentioned.

We gratefully acknowledge Nate DuRussel for greenhouse assistance, J.R. Peters and The Blackmore Co. for fertilizer, and Dümmen Orange for donating plant material.

R.G.L. is the corresponding author. E-mail: rglopez (a)msu.edu.

This is an open access article distributed under the CC BY-NC-ND license (https://creativecommons. org/licenses/by-nc-nd/4.0/). been documented as directly influencing propagation time and liner quality.

The total number of photons available over a 24-h period is known as the photosynthetic daily light integral (DLI). During peak propagation in northern latitudes, the DLI can be as low as $2 \mathrm{~mol} \cdot \mathrm{m}^{-2} \cdot \mathrm{d}^{-1}$ inside a greenhouse due to seasonal short days, low ambient radiation levels, and greenhouse glazing and infrastructure (Faust, 2011). To increase the greenhouse DLI, supplemental lighting from high-pressure sodium (HPS) lamps or light-emitting diodes can be used. A minimum DLI of $\approx 5 \mathrm{~mol} \cdot \mathrm{m}^{-2} \cdot \mathrm{d}^{-1}$ inside the greenhouse is recommended for propagation of herbaceous ornamental crops, with an increase in the DLI to $\geq 8 \mathrm{~mol} \cdot \mathrm{m}^{-2} \cdot \mathrm{d}^{-1}$ for further biomass accumulation (Lopez and Runkle, 2008).

In general, increasing the DLI increases biomass accumulation and decreases stem elongation until plants become light saturated (Currey et al., 2012; Faust et al., 2005). For example, shoot dry mass (SDM) and root dry mass (RDM) of three petunia cultivars (Petunia $\times$ hybrida) after $16 \mathrm{~d}$ of propagation increased by 1.1 to 5.1 times and 1.1 to 24 times, respectively, as DLI increased from 1.2 to $8.4 \mathrm{~mol} \cdot \mathrm{m}^{-2} \cdot \mathrm{d}^{-1}$ (Lopez and Runkle, 2008 ). Height of cuttings decreased by $25 \%$ to $36 \%$ as the DLI increased from 1.2 to 5.9 $\mathrm{mol} \cdot \mathrm{m}^{-2} \cdot \mathrm{d}^{-1}$ for liners of petunia (Lopez and Runkle, 2008). Additionally, Currey et al. (2012) reported stem length, stem caliper, and total dry mass (TDM) of diascia (Diascia barberae) increased by $76 \%, 160 \%$, and $465 \%$, respectively, as the DLI increased from 1.2 to $12.3 \mathrm{~mol} \cdot \mathrm{m}^{-2} \cdot \mathrm{d}^{-1}$. In contrast, the DLI did not affect stem length during propagation of New Guinea impatiens (Impatiens hawkeri), geranium (Pelargonium $\times$ hortorum), and petunia (Currey and Lopez, 2015). Furthermore, as the DLI increased from 2.0 to $13.4 \mathrm{~mol} \cdot \mathrm{m}^{-2} \cdot \mathrm{d}^{-1}$, the root, stem, and leaf dry mass of New Guinea impatiens increased by $211 \%, 104 \%$, and $99 \%$ respectively, after $14 \mathrm{~d}$ of DLI treatments (Currey and Lopez, 2015).

In addition to influencing growth and development of ornamental young plants, the DLI similarly influences growth of culinary herbs. Litvin-Zabal (2019) reported shoot fresh and dry mass increased when increasing the DLI for hydroponically grown mint (Mentha spp.), oregano (Origanum vulgare), sage (Salvia officinalis), and thyme (Thymus vulgaris). For example, the shoot fresh weight of mint and sage increased by 29.2 and 7.9 times as the DLI increased from 2 to 14.9 and $15.9 \mathrm{~mol} \cdot \mathrm{m}^{-2} \cdot \mathrm{d}^{-1}$, respectively, then declined thereafter (Litvin-Zabal, 2019). The SDM of mint, thyme, and oregano increased linearly from $0.4-9.5,0.02-2.9$, and $0.2-1.6 \mathrm{~g}$, respectively, as the DLI increased from 2 to $20 \mathrm{~mol} \cdot \mathrm{m}^{-2} \cdot \mathrm{d}^{-1}$ (Litvin-Zabal, 2019). For sweet basil (Ocimum basilicum), RDM was greater at a DLI of $16.5 \mathrm{~mol} \cdot \mathrm{m}^{-2} \cdot \mathrm{d}^{-1}$ compared with DLIs of 9.3, 11.5, 12.9, and $17.8 \mathrm{~mol} \cdot \mathrm{m}^{-2} \cdot \mathrm{d}^{-1}$ after $21 \mathrm{~d}$ of treatments (Dou et al., 2018). Additionally, Mapes and Xu (2014) reported the height of sage grown for 
$84 \mathrm{~d}$ to be $67 \%, 87 \%$, and $135 \%$ taller under DLIs of $6.5,4.5$, and $3.1 \mathrm{~mol} \cdot \mathrm{m}^{-2} \cdot \mathrm{d}^{-1}$, respectively, compared with a DLI of $9.2 \mathrm{~mol} \cdot \mathrm{m}^{-2} \cdot \mathrm{d}^{-1}$. The fresh shoot mass of sage stems and leaves was $155 \%$ to $215 \%$ greater when grown at a DLI of $9.2 \mathrm{~mol} \cdot \mathrm{m}^{-2} \cdot \mathrm{d}^{-1}$ compared with lower DLI treatments (Mapes and Xu, 2014). Fausey et al. (2005) also reported SDM to increase as the DLI increased from 5 to $20 \mathrm{~mol} \cdot \mathrm{m}^{-2} \cdot \mathrm{d}^{-1}$ for lavender (Lavandula angustifolia). Overall plant quality also improved from weak stems, lateral branching, and green foliage to upright stems, extensive branching, and gray foliage as the DLI increased to $20 \mathrm{~mol} \cdot \mathrm{m}^{-2} \cdot \mathrm{d}^{-1}$, concluding that a DLI of at least 15 to $20 \mathrm{~mol} \cdot \mathrm{m}^{-2} \cdot \mathrm{d}^{-1}$ should be provided for finished lavender production (Fausey et al., 2005).

In a U.S. hydroponic grower survey conducted in $2017,43 \%$ of respondents indicated that research focused on the DLI would be very beneficial (Walters et al., 2020). However, $54 \%$ indicated they used supplemental lighting during propagation compared with $45 \%$ during finished production. Of those respondents, only $45 \%$ and $32 \%$ monitored the DLI or instantaneous radiation intensity, respectively (Walters et al., 2020). It is apparent from previous research that increasing the DLI during propagation of ornamental crops and finished culinary herbs reduces production time and increases quality and yield. One of the only studies conducted on radiation quantity during seed propagation of thyme and sweet basil showed an increase in average fresh weight accumulation, but specific DLIs were not reported (Raviv and Putievsky, 1988). Thus to our knowledge little to no research has highlighted the impact the DLI has on the propagation of culinary herbs by shoot-tip cuttings.

Therefore, the objective of our study was to quantify the morphological and physiological effects of the DLI on the vegetative propagation of five commercially important culinary herbs. We hypothesized that propagation DLIs $\geq 10 \mathrm{~mol} \cdot \mathrm{m}^{-2} \cdot \mathrm{d}^{-1}$ would provide the highest quality liner with greater RDM, stem caliper, and shorter stem lengths compared with DLIs of $\leq 5 \mathrm{~mol} \cdot \mathrm{m}^{-2} \cdot \mathrm{d}^{-1}$.

\section{Materials and Methods}

Stock plants and environment. Stock plants of Greek oregano (Origanum vulgare var. hirtum), sage 'Extrakta', and thyme 'German Winter' (Johnny's Selected Seeds, Fairfield, ME), spearmint 'Spanish' (Mentha spicata) (Hishtil, Afula, Israel), and rosemary 'Arp' (Rosmarinus officinalis) (Dümmen Orange NA, Inc., Columbus, $\mathrm{OH}$ ) were grown in 15.3-cm (1.3-L; The HC Companies, Twinsburg, $\mathrm{OH}$ ) round containers filled with a $70 \%$ peat, $21 \%$ perlite, and $9 \%$ vermiculite mixture (Suremix; Michigan Grower Products, Inc., Galesburg, MI). Plants were irrigated as necessary with reverse osmosis water and a water-soluble fertilizer (MSU Orchid RO Water Special 13N-1.8P-12.5K; Greencare Fertilizers, Inc., Kankakee, IL) providing $\left(\mathrm{mg} \cdot \mathrm{L}^{-1}\right): 125 \mathrm{~N}, 12 \mathrm{P}, 120 \mathrm{~K}, 78$
$\mathrm{Ca}, 19 \mathrm{Mg}, 1.7 \mathrm{Fe}, 0.9 \mathrm{Mn}, 0.4 \mathrm{Cu}$ and $\mathrm{Zn}$, and $0.2 \mathrm{~B}$ and Mo.

Oregano, spearmint, rosemary, and thyme were grown in a glass-glazed greenhouse in the Plant Science Research Greenhouse ranges at Michigan State University [MSU, East Lansing, MI (lat. $43^{\circ} \mathrm{N}$ )] with an air average daily temperature of $21 \pm 4{ }^{\circ} \mathrm{C}$ and a mean DLI of $12.1 \mathrm{~mol} \cdot \mathrm{m}^{-2} \cdot \mathrm{d}^{-1}$. The mean DLI one month before cutting harvest was $11.6,10.1$, and $9.7 \mathrm{~mol} \cdot \mathrm{m}^{-2} \cdot \mathrm{d}^{-1}$ for replications 1,2 , and 3 , respectively. Oregano, spearmint, thyme (long-day plants) and rosemary (photoperiodic response unknown) were grown under a 9-h photoperiod to maintain vegetative growth. The photoperiod consisted of a truncated 9-h natural day achieved by using blackout cloth from 1700 to $0800 \mathrm{HR}$. From 0800 to $1700 \mathrm{HR}$, HPS lamps (LR48877; P.L. Light Systems; Beamsville, Ont., Canada) provided a supplemental photosynthetic photon flux density $(P P F D)$ of $60.2 \pm 4.2 \mu \mathrm{mol} \cdot \mathrm{m}^{-2} \cdot \mathrm{s}^{-1}$ at plant height [as measured with a spectrometer (LI180; LI-COR Biosciences, Lincoln, NE)] when the ambient greenhouse PPFD was $<400 \mu \mathrm{mol} \cdot \mathrm{m}^{-2} \cdot \mathrm{s}^{-1}$. Sage stock plants, which are presumed to be short-day plants, were maintained under a $16-\mathrm{h}$ photoperiod at an air average daily temperature of $22 \pm 3{ }^{\circ} \mathrm{C}$ and a mean DLI of $17.5 \mathrm{~mol} \cdot \mathrm{m}^{-2} \cdot \mathrm{d}^{-1}$. The mean DLI one month before cuttings were harvested were $11.3,11.7$, and $10.3 \mathrm{~mol} \cdot \mathrm{m}^{-2} \cdot \mathrm{d}^{-1}$ for replications 1,2 , and 3 , respectively. The photoperiod consisted of natural daylengths with day-extension lighting from HPS lamps that delivered a supplemental PPFD of 60.2 $\pm 4.2 \mu \mathrm{mol} \cdot \mathrm{m}^{-2} \cdot \mathrm{s}^{-1}$ at plant height from 0600 to $2200 \mathrm{HR}$. All stock plants were periodically cut back as necessary to increase branching and number of harvestable cuttings.

Plant material and callusing environment. One hundred fifty, 3- to 4-cm vegetative stemtip cuttings were excised from stock plants of oregano, rosemary, sage, spearmint, and thyme on 9 Sept. 2019, 3 Oct. 2019, and 7 Jan. 2020. Cuttings of each genus were inserted immediately, without rooting hormone, into two 72 -cell trays $(28-\mathrm{mL}$ individual cell volume; Landmark Plastics, Akron, $\mathrm{OH})$ that were divided in half and filled with a propagation mix made from $1: 1(\mathrm{v} / \mathrm{v}) 50 \%$ of soilless substrate mentioned previously (Suremix; Michigan Grower Products Inc.) and $50 \%$ coarse perlite.

All four trays per genus were placed in a glass-glazed greenhouse with an air average daily temperature set point of $24{ }^{\circ} \mathrm{C}$ and a vapor-pressure deficit (VPD) of $0.3 \mathrm{kPa}$ on propagation benches with a root-zone heating (Biotherm Benchwarmer Kit; TrueLeaf Technologies, Petaluma, CA) set point of $24{ }^{\circ} \mathrm{C}$ for $5 \mathrm{~d}$ to callus. A Priva Environmental Monitoring Box (Integro 725-3030; Priva North America, Vineland Station, Ont., Canada) positioned in the middle of each greenhouse compartment housed a thermocouple to measure air temperature and a thermocouple inserted into a moist wick to measure the VPD. The root-zone heating temperature was measured with two thermocouples and a thermistor, which were placed into three cells along the long edge of a propagation tray, 2.6 $\mathrm{cm}$ in depth, filled with propagation substrate as mentioned previously. A DLI of $\approx 5$ $\mathrm{mol} \cdot \mathrm{m}^{-2} \cdot \mathrm{d}^{-1}$ was maintained with the use of a $56 \%$ aluminum shadecloth (Solaro 5220 D O; Ludvig Svensson Inc., Charlotte, NC) placed over the bench. When the outdoor solar radiation intensity was below $\approx 400 \mu \mathrm{mol} \cdot \mathrm{m}^{-2} \cdot \mathrm{s}^{-1}$ [as measured by an LI-190R quantum sensor (LI-COR Biosciences)], HPS supplemental lighting was turned on to create a 16 -h photoperiod (0600 to $2200 \mathrm{HR}$ ). An IR sensor (Type T, OS36-01; Omega Engineering, Stamford, $\mathrm{CT}$ ) was pointed $\approx 2.0 \mathrm{~cm}$ above spearmint leaves to measure plant temperature. Averages of air, plant, and root-zone temperature, the DLI, and VPD for all replications are shown in Table 1.

Overhead mist containing reverseosmosis water supplemented with watersoluble fertilizer (MSU Plug Special $13 \mathrm{~N}-$ 2.2P-10.8K; Greencare Fertilizers, Inc.) and a micronutrient supplement (M.O.S.T.; JR Peters, Inc., Allentown, PA) was provided as necessary from 0500 to $2300 \mathrm{HR}$. The overhead mist delivered the following $\left(\mathrm{mg} \cdot \mathrm{L}^{-1}\right)$ : $60 \mathrm{~N}, 10 \mathrm{P}, 50 \mathrm{~K}, 28 \mathrm{Ca}, 27 \mathrm{~S}, 17 \mathrm{Mn}, 16 \mathrm{Fe}$, $10 \mathrm{Zn}, 5 \mathrm{Mg}$ and $5 \mathrm{Cu}, 3 \mathrm{~B}$, and $0.2 \mathrm{Mo}$. The mist was regulated by an environmental computer that accounted for the function of time and accumulated $P P F D$. A line quantum sensor (Apogee Instruments, Inc., Logan, UT) positioned in the center of the propagation house recorded radiation intensity every $10 \mathrm{~s}$. When the integrated radiation intensity achieved $0.20 \mathrm{~mol} \cdot \mathrm{m}^{-2} \cdot \mathrm{h}^{-1}$ or after $60 \mathrm{~min}$, whichever first occurred, the mist would turn on for $5 \mathrm{~s}$. A VPD of $0.3 \mathrm{kPa}$ was maintained by the injection of steam.

Daily light integral treatments. After callusing, one tray of each species was randomly distributed among four different DLIs that were created under aluminum shadecloth providing shading percentages per the manufacturer of $76 \%$ (Solaro 7330 O FB; Ludvig Svensson Inc.), 56\% (Solaro 5220 D O; Ludvig Svensson Inc.), or $36 \%$ (Solaro 3215 D O FB; Ludvig Svensson Inc.) shading or no shade (Table 1). Each DLI treatment was randomized between the two propagation houses and three benches in each house. Quantum sensors were positioned in the middle of each bench to record the radiation intensity; and air, plant, and root-zone temperature were measured as stated above. All measurements were recorded every $10 \mathrm{~s}$, and averages accumulated every hour using a data logger (CR-1000; Campbell Scientific, Logan, UT). Mist was reduced every $4 \mathrm{~d}$ during the experiment and discontinued $7 \mathrm{~d}$ before data collection. Liners were irrigated with the same water-soluble fertilizer (MSU Plug Special 13N-2.2P-10.8K; Greencare Fertilizers, Inc.) and a micronutrient supplement (M.O.S.T.; JR Peters, Inc.).

Data collection. Ten cuttings per DLI treatment were harvested $9 \mathrm{~d}$ (spearmint) or $16 \mathrm{~d}$ (all other genera) after callusing. Spearmint was harvested on 23 Sept. 2019, 17 Oct. 2019, and 21 Jan. 2020, while all other genera 
Table 1. Percent shade; daily light integral (DLI); root-zone, plant, and air temperatures; and vapor-pressure deficit (VPD) averages ( \pm SD) for callusing and postcallusing during propagation treatments.

\begin{tabular}{|c|c|c|c|c|c|c|}
\hline \multirow[b]{2}{*}{ Date } & \multirow[b]{2}{*}{ Shade $(\%)$} & \multirow[b]{2}{*}{$\operatorname{DLI}\left(\mathrm{mol} \cdot \mathrm{m}^{-2} \cdot \mathrm{d}^{-1}\right)$} & \multicolumn{3}{|c|}{ Temperature $\left({ }^{\circ} \mathrm{C}\right)$} & \multirow[b]{2}{*}{$\mathrm{VPD}(\mathrm{kPa})$} \\
\hline & & & Root-zone & Plant & Air & \\
\hline & \multicolumn{6}{|c|}{ Callus } \\
\hline 9 Sept. 2019 & 56 & $4.3 \pm 0.5$ & $22.1 \pm 2.9$ & $26.4 \pm 2.2$ & $23.3 \pm 3.9$ & $0.4 \pm 0.3$ \\
\hline 3 Oct. 2019 & 56 & $4.6 \pm 0.7$ & $23.4 \pm 2.1$ & $26.0 \pm 1.7$ & $23.0 \pm 1.9$ & $0.3 \pm 0.1$ \\
\hline 7 Jan. 2020 & 56 & $4.8 \pm 0.2$ & $22.0 \pm 0.8$ & $26.1 \pm 0.7$ & $23.8 \pm 0.5$ & $0.3 \pm 0.2$ \\
\hline \multirow[t]{4}{*}{9 Sept. 2019} & 0 & $16.4 \pm 2.9$ & $\begin{aligned} & \text { Pos } \\
23.1 \pm & 3.5\end{aligned}$ & $27.0 \pm 3.2$ & $23.4 \pm 3.7^{z}$ & $0.4 \pm 0.3^{z}$ \\
\hline & 36 & $9.4 \pm 1.8$ & $23.5 \pm 3.2$ & $25.1 \pm 3.4$ & y & - \\
\hline & 56 & $5.8 \pm 0.8$ & $23.9 \pm 2.8$ & $24.9 \pm 3.4$ & - & - \\
\hline & 76 & $3.1 \pm 0.2$ & $22.4 \pm 2.8$ & $25.0 \pm 2.8$ & - & - \\
\hline \multirow[t]{4}{*}{3 Oct. 2019} & 0 & $12.3 \pm 1.3$ & $24.2 \pm 2.8$ & $27.0 \pm 2.3$ & $24.2 \pm 1.3^{z}$ & $0.3 \pm 0.2^{z}$ \\
\hline & 36 & $8.9 \pm 1.5$ & $24.9 \pm 1.6$ & $25.1 \pm 2.0$ & - & - \\
\hline & 56 & $5.4 \pm 0.7$ & $24.1 \pm 1.7$ & $25.6 \pm 1.6$ & - & - \\
\hline & 76 & $2.9 \pm 0.4$ & $24.1 \pm 1.6$ & $25.3 \pm 1.7$ & - & - \\
\hline \multirow[t]{4}{*}{7 Jan. 2020} & 0 & $11.2 \pm 0.7$ & $23.2 \pm 1.1$ & $27.0 \pm 1.8$ & $23.9 \pm 0.5^{z}$ & $0.3 \pm 0.1^{\mathrm{z}}$ \\
\hline & 36 & $6.2 \pm 0.3$ & $23.4 \pm 1.7$ & $26.0 \pm 1.4$ & - & - \\
\hline & 56 & $4.0 \pm 0.2$ & $22.2 \pm 0.7$ & $24.7 \pm 1.1$ & - & - \\
\hline & 76 & $2.8 \pm 0.2$ & $23.7 \pm 0.7$ & $23.8 \pm 2.5$ & - & - \\
\hline
\end{tabular}

${ }^{\mathrm{z}}$ Averaged between two propagation houses.

${ }^{\mathrm{y}}$ Air and VPD were the same for the following DLI treatments within each replication.

were collected on 30 Sept. 2019, 24 Oct. 2019, and 28 Jan. 2020. Before measurements were taken, each cutting was assessed for pullability and the substrate was gently washed from the roots and shoots. Pullability refers to the ability to pull the liner from the cell while keeping at least $95 \%$ of the substrate intact. On each harvest date, stem length was measured with a ruler from the base of the stem to the apical meristem, and stem diameter was measured by a digital caliper below the first true leaves. Each cutting was separated into roots and shoots, placed in a drying oven at $70{ }^{\circ} \mathrm{C}$ for $3 \mathrm{~d}$, and weighed on a balance to record the RDM

Table 2. Regression equations for root, shoot, and total dry mass, root-to-shoot ratio, stem length, stem caliper, sturdiness quotient, and quality index for five culinary herb liners. The $x$ is the daily light integral (DLI; mol $\cdot \mathrm{m}^{-2} \cdot \mathrm{d}^{-1}$ ), and plots for equations are in Figs. 1 and 2 .

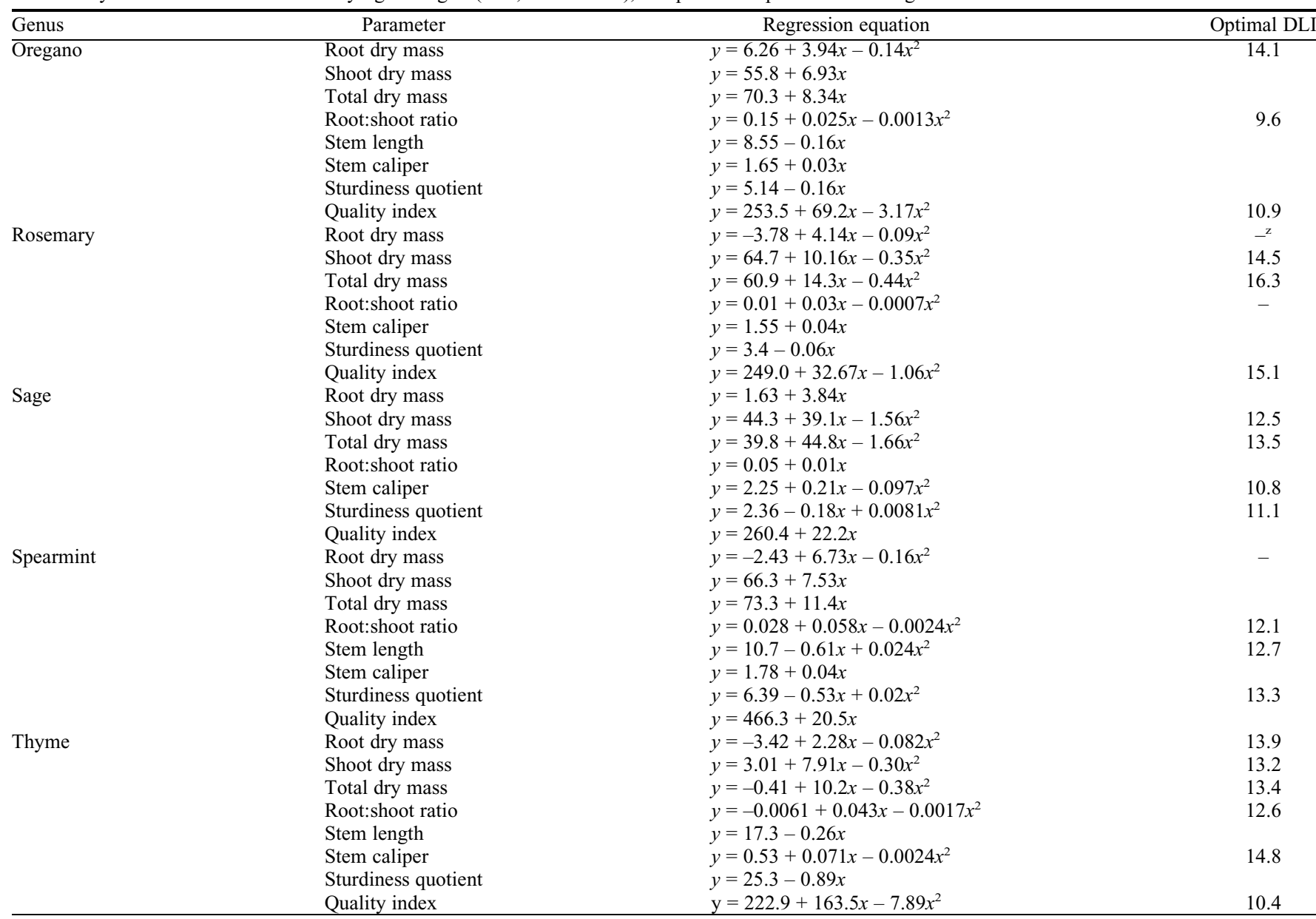

${ }^{\mathrm{z}}$ Optimal DLI calculated outside of studied range. 
and SDM, respectively. Measurements of stem length, stem caliper, RDM, and SDM were used to determine the root-to-shoot ratio (R:S; R:S = RDM/SDM), total dry mass (TDM $=\mathrm{RDM}+\mathrm{SDM})$, sturdiness quotient (SQ; SQ = stem length/stem caliper), and the quality index [QI; QI $=\mathrm{TDM} \times(\mathrm{R}: \mathrm{S}+\mathrm{SQ})$ ] (Currey et al., 2013).

Experimental design and statistical analysis. The experiment was designed as a randomized complete block with DLI as a random factor. The experimental units were the 36-cell trays, which were randomly assigned to each DLI treatment. The experiment was performed three times across benches and propagation houses with 10 subsamples (individual cuttings) per DLI treatment. Data were analyzed using the generalized linear mixed model procedure (PROC GLIMMIX) and linear and quadratic regression (PROC REG) in SAS (version 9.4; SAS Institute, Cary, NC) with means separated by Fisher's least significant difference test at $P \leq 0.05$. When linear and quadratic regression formulas were both significant, the line with the higher coefficient of determination value $\left(r^{2}\right.$ or $\left.R^{2}\right)$ was the deciding factor.

\section{Results}

For all crops, the RDM, SDM, and TDM increased as the DLI increased to cropspecific optimums. The optimal DLI for oregano and thyme were 14.1 and 13.9 $\mathrm{mol} \cdot \mathrm{m}^{-2} \cdot \mathrm{d}^{-1}$, respectively, where the $\mathrm{RDM}$ were $110 \%$ and $436 \%$ greater, respectively, than a DLI of $2.8 \mathrm{~mol} \cdot \mathrm{m}^{-2} \cdot \mathrm{d}^{-1}$ (Table 2, Fig. 1A). Further increases in the DLI for these genera did not result in an increase in RDM. As the DLI increased from 2.8 to 16.4 $\mathrm{mol} \cdot \mathrm{m}^{-2} \cdot \mathrm{d}^{-1}$, the RDM of sage increased linearly by $421 \%$ (Fig. 1B). The RDM of rosemary and spearmint increased curvilinearly as the DLI increased from 2.8 to $16.4 \mathrm{~mol} \cdot \mathrm{m}^{-2} \cdot \mathrm{d}^{-1}$; however, the optimal DLIs were outside of the range studied (Table 2, Fig. 1A and $\mathrm{B}$ ). The SDM of oregano and spearmint increased linearly to 169 and $189 \mathrm{mg}$, respectively, as the DLI increased from 2.8 to $16.4 \mathrm{~mol} \cdot \mathrm{m}^{-2} \cdot \mathrm{d}^{-1}$. The SDM of rosemary, sage, and thyme increased curvilinearly with optimal DLIs occurring at $14.5(138 \mathrm{mg}), 12.5(290 \mathrm{mg})$, and 13.2 $(55 \mathrm{mg}) \mathrm{mol} \cdot \mathrm{m}^{-2} \cdot \mathrm{d}^{-1}$, respectively (Table 2 , Fig. 1C and D). Additionally, the TDM of oregano and spearmint increased linearly from 93 to $207 \mathrm{mg}$ and 105 to $260 \mathrm{mg}$, respectively, as the DLI increased from 2.8 to $16.4 \mathrm{~mol} \cdot \mathrm{m}^{-2} \cdot \mathrm{d}^{-1}$, respectively (Fig. 1E). The TDM of rosemary, sage, and thyme increased curvilinearly by $103 \%, 125 \%$, and $216 \%$, respectively, at optimal DLIs of $16.3,13.5$, and $13.4 \mathrm{~mol} \cdot \mathrm{m}^{-2} \cdot \mathrm{d}^{-1}$, respectively (Table 2, Fig. 1E and F).

For all crops, the R:S increased to cropspecific DLIs (Table 2, Fig. $1 \mathrm{G}$ and $\mathrm{H}$ ). The $\mathrm{R}: \mathrm{S}$ of sage increased linearly from 0.08 to 0.25 as the DLI increased from 2.8 to 16.4 mol. $\mathrm{m}^{-2} \cdot \mathrm{d}^{-1}$ (Fig. 1H). The R:S increased curvilinearly for oregano, rosemary, spearmint, and thyme as the DLI increased from 2.8 to $16.4 \mathrm{~mol} \cdot \mathrm{m}^{-2} \cdot \mathrm{d}^{-1}$ (Fig. $1 \mathrm{G}$ and $\mathrm{H}$ ). For instance, the R:S of oregano increased from 0.21 to 0.27 as the DLI increased from 2.8 to $9.6 \mathrm{~mol} \cdot \mathrm{m}^{-2} \cdot \mathrm{d}^{-1}$, respectively, then decreased to 0.21 at a DLI of $16.4 \mathrm{~mol} \cdot \mathrm{m}^{-2} \cdot \mathrm{d}^{-1}$ (Table 2, Fig. 1G). The R:S of rosemary increased curvilinearly from 0.09 to 0.28 as the DLI increased from 2.8 to $16.4 \mathrm{~mol} \cdot \mathrm{m}^{-2} \cdot \mathrm{d}^{-1}$, respectively, but the optimal DLI was calculated outside of the studied range (Table 2, Fig. $1 \mathrm{H}$ ). Additionally, as the DLI increased from 2.8 to $12.1 \mathrm{~mol} \cdot \mathrm{m}^{-2} \cdot \mathrm{d}^{-1}$, the $\mathrm{R}: \mathrm{S}$ for spearmint increased from 0.17 to 0.38 , respectively, and decreased to 0.33 at a DLI of $16.4 \mathrm{~mol} \cdot \mathrm{m}^{-2} \cdot \mathrm{d}^{-1}$ (Table 2, Fig. $1 \mathrm{G}$ ). From a DLI of 2.8 to $12.6 \mathrm{~mol} \cdot \mathrm{m}^{-2} \cdot \mathrm{d}^{-1}$, the $\mathrm{R}: \mathrm{S}$ of thyme increased from 0.10 to 0.27 , respectively, and decreased to 0.24 at a DLI of 16.4 $\mathrm{mol} \cdot \mathrm{m}^{-2} \cdot \mathrm{d}^{-1}$ (Table 2, Fig. $1 \mathrm{G}$ ).

Stem length of oregano, spearmint, and thyme was influenced by DLI, but it did not influence rosemary or sage (Fig. 2A and B). The stem length of spearmint decreased curvilinearly by $12 \%$ as the DLI increased from 2.8 to $12.7 \mathrm{~mol} \cdot \mathrm{m}^{-2} \cdot \mathrm{d}^{-1}$, then slightly increased as the DLI increased to 16.4 $\mathrm{mol} \cdot \mathrm{m}^{-2} \cdot \mathrm{d}^{-1}$ (Table 2, Fig. 2A). Stem length of oregano and thyme decreased linearly by $36 \%$ and $27 \%$, respectively, as the DLI increased from 2.8 to $16.4 \mathrm{~mol} \cdot \mathrm{m}^{-2} \cdot \mathrm{d}^{-1}$ (Fig. 2A). As the DLI increased, the stem caliper for all crops increased variably (Fig. 2C and D). The stem caliper of sage and thyme increased curvilinearly by $23 \%$ and $49 \%$, respectively, from a DLI of $2.8 \mathrm{~mol} \cdot \mathrm{m}^{-2} \cdot \mathrm{d}^{-1}$ to DLI optimums of 10.8 and $14.8 \mathrm{~mol} \cdot \mathrm{m}^{-2} \cdot \mathrm{d}^{-1}$, respectively (Table 2, Fig. 2C and D). Stem caliper of oregano, rosemary, and spearmint increased linearly as the DLI increased from 2.8 to $16.4 \mathrm{~mol} \cdot \mathrm{m}^{-2} \cdot \mathrm{d}^{-1}$ by $26 \%, 28 \%$, and $30 \%$, respectively (Fig. $2 \mathrm{C}$ and $\mathrm{D}$ ).

The SQ decreased curvilinearly for sage and spearmint as the DLI increased to optimums of 11.1 and $13.3 \mathrm{~mol} \cdot \mathrm{m}^{-2} \cdot \mathrm{d}^{-1}$, respectively (Table 2, Fig. 2E and F). For spearmint, the SQ decreased by $27 \%$ as the DLI increased from 2.8 to $13.3 \mathrm{~mol} \cdot \mathrm{m}^{-2} \cdot \mathrm{d}^{-1}$, respectively, then increased as the DLI increased to $16.4 \mathrm{~mol} \cdot \mathrm{m}^{-2} \cdot \mathrm{d}^{-1}$ (Table 2, Fig. 2E). As the DLI increased, the SQ of oregano, rosemary, and thyme decreased linearly (Figs. $2 \mathrm{E}$ and $\mathrm{F}$ and $3 \mathrm{~A}$ ). For example, as the DLI increased from 2.8 to $16.4 \mathrm{~mol} \cdot \mathrm{m}^{-2} \cdot \mathrm{d}^{-1}$, the SQ of thyme decreased by $53 \%$ (Fig. 3A). The QI of oregano, rosemary, and thyme increased curvilinearly to optimal DLIs of $10.9,15.1$, and 10.4 $\mathrm{mol} \cdot \mathrm{m}^{-2} \cdot \mathrm{d}^{-1}$, respectively, yielding a QI of 631 , 501 , and 1070 , respectively (Table 2 , Figs. $2 \mathrm{G}$ and $\mathrm{H}$ and $3 \mathrm{~B}$ ). As the DLI increased from 2.8 to $16.4 \mathrm{~mol} \cdot \mathrm{m}^{-2} \cdot \mathrm{d}^{-1}$, the QI of spearmint increased by $53 \%$ (Fig. 2G). Additionally, the QI of sage increased linearly by $93 \%$ as the DLI increased from 2.8 to $16.4 \mathrm{~mol} \cdot \mathrm{m}^{-2} \cdot \mathrm{d}^{-1}$ (Fig. 2H). Liner pullability of only sage was affected by DLI treatments, however results were inconsistent (data not provided).

\section{Discussion}

High-quality plugs and liners have a high $\mathrm{RDM}$, are compact, and have thick stems to allow for ease of transportation and trans- planting (Currey et al., 2012; Pramuk and Runkle, 2005). Plant characteristics such as RDM, SDM, leaf area, stem length, and caliper give insight to overall plant quality and are greatly influenced by radiation intensity (Currey et al., 2012; Faust et al., 2005; Pramuk and Runkle, 2005). In this experiment, the RDM, SDM, and stem caliper of all culinary herbs increased and stem length decreased or had no change to a genusspecific DLI maxima as the DLI increased from 2.8 to $16.4 \mathrm{~mol} \cdot \mathrm{m}^{-2} \cdot \mathrm{d}^{-1}$ (Figs. 1A-D and $2 \mathrm{~A}-\mathrm{D})$. These data are like previous findings in young ornamental plant production. For example, as the DLI increased from 1.2 to $12.3 \mathrm{~mol} \cdot \mathrm{m}^{-2} \cdot \mathrm{d}^{-1}$, the RDM of argyranthemum (Argyranthemum frutescens), diascia, nemesia (Nemesia fruticans), osteospermum (Osteospermum ecklonis), scaevola (Scaevola hybrid), and sutera (Sutera cordata) cuttings also increased $14 \mathrm{~d}$ after transfer (Currey et al., 2012). Additionally, increases in the RDM and SDM of New Guinea impatiens, geranium, and petunia cuttings occurred $14 \mathrm{~d}$ after transferring as the DLI increased from $2.0-2.4$ to $13.0-14.2 \mathrm{~mol} \cdot \mathrm{m}^{-2} \cdot \mathrm{d}^{-1}$ (Currey and Lopez, 2015).

In this study, genus-specific DLIs were identified, with the highest RDM of sage, spearmint, and rosemary occurring at 16.4 $\mathrm{mol} \cdot \mathrm{m}^{-2} \cdot \mathrm{d}^{-1}$, oregano at $14.1 \mathrm{~mol} \cdot \mathrm{m}^{-2} \cdot \mathrm{d}^{-1}$, and thyme at $13.9 \mathrm{~mol} \cdot \mathrm{m}^{-2} \cdot \mathrm{d}^{-1}$ (Table 2, Fig. 1C and D). Additionally, at a DLI of 16.4 $\mathrm{mol} \cdot \mathrm{m}^{-2} \cdot \mathrm{d}^{-1}$, the SDM and TDM of oregano and spearmint were the greatest, whereas the SDM of rosemary, sage, and thyme were greatest at $14.5,12.5$, and $13.2 \mathrm{~mol} \cdot \mathrm{m}^{-2} \cdot \mathrm{d}^{-1}$, respectively (Table 2, Fig. 1E-H). Although these genus-specific DLIs were high for this study, DLIs of 11.2 to $16.4 \mathrm{~mol} \cdot \mathrm{m}^{-2} \cdot \mathrm{d}^{-1}$ are categorized as medium-light during finishing (Faust, 2011). Additionally, the SDM of hydroponically grown mint, oregano, and thyme increased as the DLI increased to 20 $\mathrm{mol} \cdot \mathrm{m}^{-2} \cdot \mathrm{d}^{-1}$, while the SDM of sage increased to a DLI of $15.9 \mathrm{~mol} \cdot \mathrm{m}^{-2} \cdot \mathrm{d}^{-1}$ (Litvin-Zabal, 2019). Similarly, Walters (2020) also reported the SDM of hydroponically grown sage and spearmint increased as the DLI increased from 6 to $18 \mathrm{~mol} \cdot \mathrm{m}^{-2} \cdot \mathrm{d}^{-1}$. Furthermore, Litvin-Zabal (2019) classified hydroponically grown mint and sage as medium-light plants during finishing; these had optimal DLIs of 19.0 and $14.8 \mathrm{~mol} \cdot \mathrm{m}^{-2} \cdot \mathrm{d}^{-1}$, respectively. In comparison, oregano and thyme were reported to be high to very highlight plants because their optimal DLIs were $\geq 20 \mathrm{~mol} \cdot \mathrm{m}^{-2} \cdot \mathrm{d}^{-1}$ (Litvin-Zabal, 2019). Not surprisingly, the greatest RDM, SDM, and TDM of oregano, sage, spearmint, and thyme were under DLIs of $11.2-16.4 \mathrm{~mol} \cdot \mathrm{m}^{-2} \cdot \mathrm{d}^{-1}$, which is lower than the optimum DLI for these crops at finishing (Litvin-Zabal, 2019; Walters, 2020).

The R:S of oregano, spearmint, and thyme was greatest at DLIs generally lower than those for high RDM, SDM, and TDM (Table 2, Fig. $1 \mathrm{G}$ and $\mathrm{H}$ ). In the case of the $\mathrm{R}: \mathrm{S}$ of thyme, the lower optimal DLI is most likely due to small SDM accumulation at lower DLIs. For example, the R:S of thyme was 


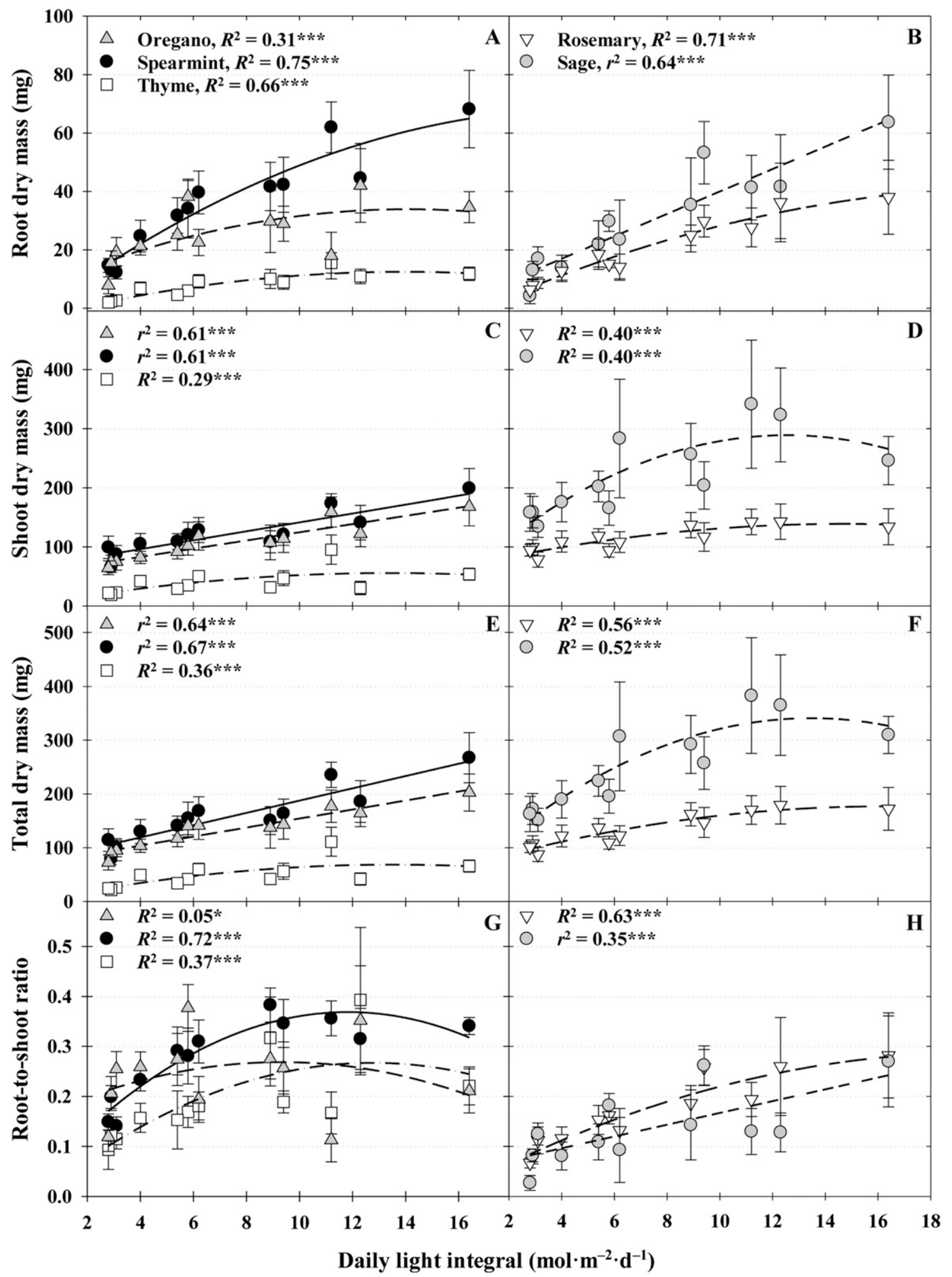

Fig. 1. The root dry mass (A-B), shoot dry mass $(\mathbf{C}-\mathbf{D})$, total dry mass $(\mathbf{E}-\mathbf{F})$, and root-to-shoot ratio $(\mathbf{G}-\mathbf{H})$ for liners of oregano, rosemary, sage, and thyme after $16 \mathrm{~d}$ and spearmint after $9 \mathrm{~d}$ of daily light integral treatments. Each symbol represents the mean of 10 plants, and error bars represent SES of the mean. Regression lines are presented with corresponding $r^{2}$ and $R^{2}$ presented. * and *** indicate significant at $P \leq 0.05$ or 0.001 , respectively.

greatest at an optimal DLI of $12.6 \mathrm{~mol} \cdot \mathrm{m}^{-2} \cdot \mathrm{d}^{-1}$, but the optimal DLI for RDM and SDM was 13.9 and $13.2 \mathrm{~mol} \cdot \mathrm{m}^{-2} \cdot \mathrm{d}^{-1}$, respectively (Table 2, Fig. 1G). Even though a DLI of $16.4 \mathrm{~mol} \cdot \mathrm{m}^{-2} \cdot \mathrm{d}^{-1}$ resulted in the highest accumulation of RDM, SDM, and/or TDM of oregano and spearmint, the R:S indicates that the cutting is allocating more energy into the roots at a lower DLI, which is more desirable for young plants (Currey et al., 2012). This is in agreement with previous research on New Guinea impatiens, which had a higher TDM under a DLI of 15.6 $\mathrm{mol} \cdot \mathrm{m}^{-2} \cdot \mathrm{d}^{-1}$ but had a slightly greater $\mathrm{R}: \mathrm{S}$ under a DLI of $8.5 \mathrm{~mol} \cdot \mathrm{m}^{-2} \cdot \mathrm{d}^{-1}$ after $14 \mathrm{~d}$
(Currey and Lopez, 2012). Thus, it may be possible that higher DLIs $\left(>16.4 \mathrm{~mol} \cdot \mathrm{m}^{-2} \cdot \mathrm{d}^{-1}\right)$ may not be necessary to produce a highquality culinary herb liner as we had originally hypothesized.

As the DLI increased, stem length of oregano, spearmint, and thyme rooted 


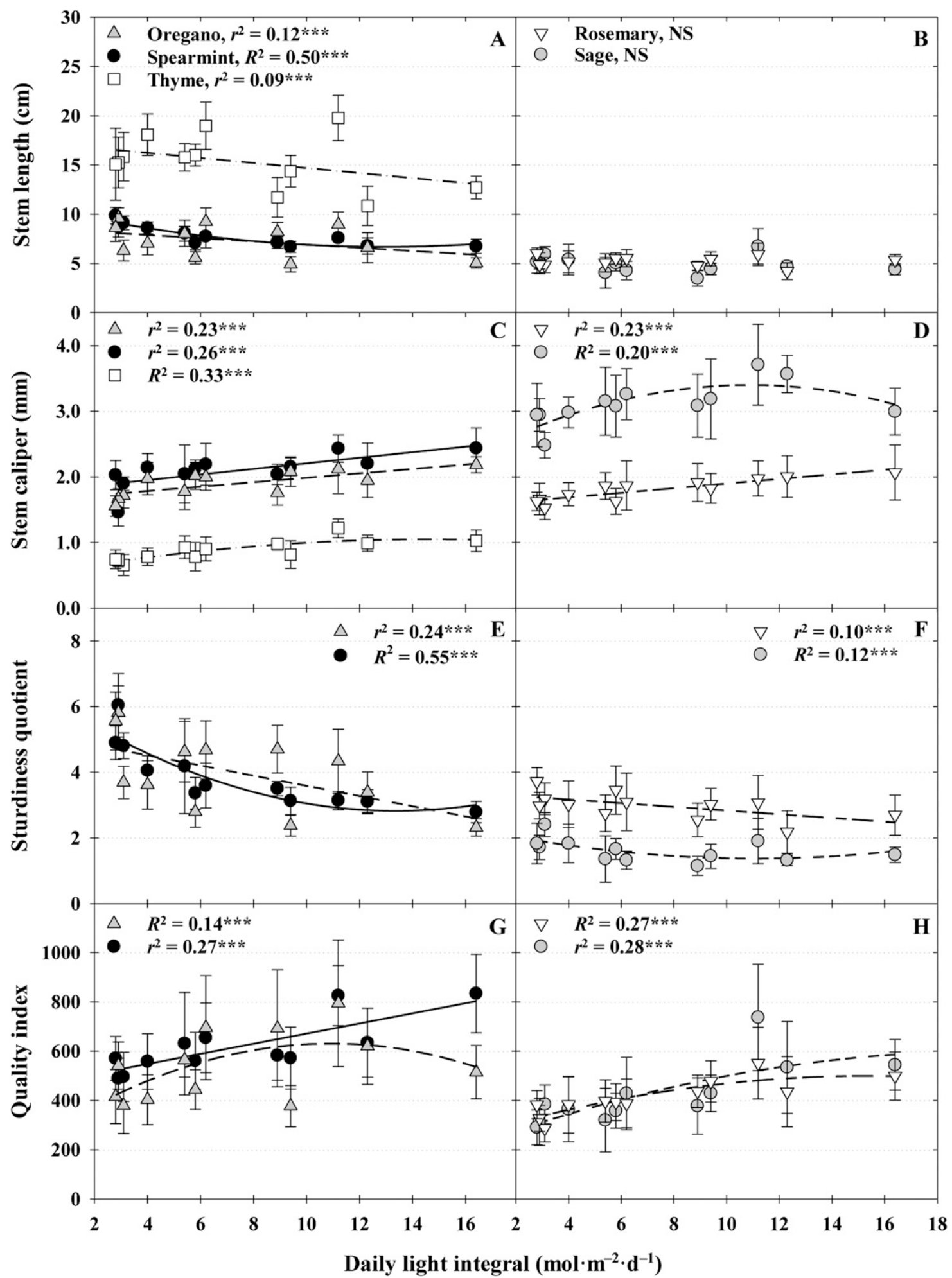

Fig. 2. The stem length (A-B), stem caliper $(\mathbf{C}-\mathbf{D})$, sturdiness quotient $(\mathbf{E}-\mathbf{F})$, and quality index $(\mathbf{G}-\mathbf{H})$ for liners of oregano, rosemary, sage, and thyme for $16 \mathrm{~d}$ and spearmint for $9 \mathrm{~d}$ of daily light integral treatments. Each symbol represents the mean of 10 plants, and error bars represent SES of the mean. Regression lines are presented for significant correlations only with corresponding $r^{2}$ and $R^{2}$ presented. Ns and $* * *$ indicate nonsignificant or significant at $P \leq 0.001$, respectively.

cuttings was generally reduced (Fig. 2A). Similarly, stem length of impatiens (Impatiens walleriana) and salvia (Salvia splendens) seedlings (Pramuk and Runkle, 2005), angelonia (Angelonia angustifolia) and osteospermum (Hutchinson et al., 2012) rooted cuttings, and yarrow (Achillea mille- folium) and lavender finished plants (Fausey et al., 2005) was reduced as the DLI increased.

However, we postulate that stem length may be genus-dependent rather than DLIdependent because stem length of rosemary and sage were not influenced by the DLI.
Like the current study, the height of hydroponically grown sage and spearmint were not influenced by DLIs ranging from 6 to 18 $\mathrm{mol} \cdot \mathrm{m}^{-2} \cdot \mathrm{d}^{-1}$ at 14 to $28 \mathrm{~d}$ after transplant (Walters, 2020). Additionally, it was reported that the DLI did not influence New Guinea impatiens, geranium, and petunia, despite 


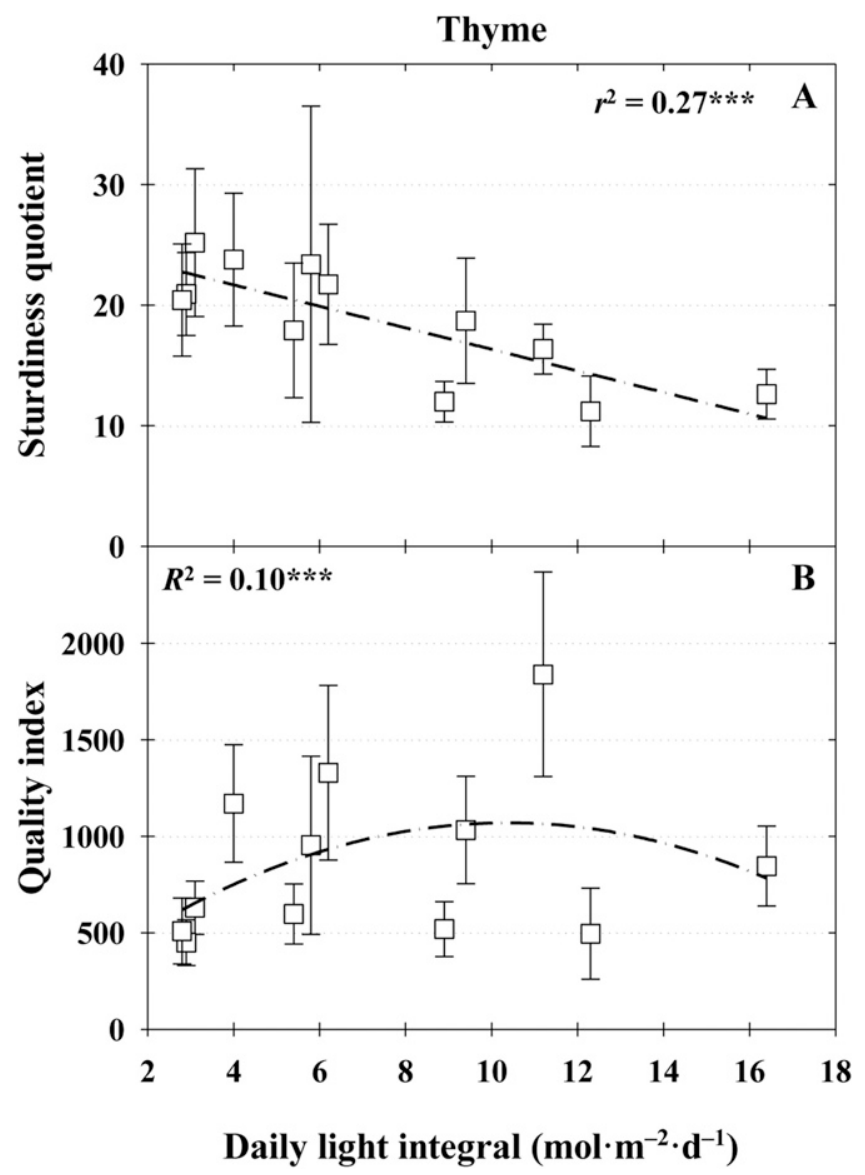

Fig. 3. The sturdiness quotient (A) and quality index (B) for liners of thyme after $16 \mathrm{~d}$ of daily light integral treatments. Each symbol represents the mean of 10 plants, and error bars represent the SES of the mean. Regression lines are presented with corresponding $r^{2}$ and $R^{2}$ presented. *** indicates significant at $P \leq$ 0.001 .

increasing stem lengths (Currey and Lopez, 2015). Furthermore, it is possible that the negligible difference in the stem length of sage and rosemary were observed due to the short length of the experiment. For example, sage grown for $84 \mathrm{~d}$ under a DLI of 9.2 $\mathrm{mol} \cdot \mathrm{m}^{-2} \cdot \mathrm{d}^{-1}$ had shorter stems $(12.1 \mathrm{~cm})$ compared with those grown under DLIs of 3.1 $(28.5 \mathrm{~cm}), 4.5(22.7 \mathrm{~cm})$, and $6.5 \mathrm{~mol} \cdot \mathrm{m}^{-2} \cdot \mathrm{d}^{-1}$ $(20.3 \mathrm{~cm})$ (Mapes and $\mathrm{Xu}, 2014)$.

For all culinary herbs studied, the stem caliper increased as the DLI increased to genus-specific maximums of $16.4 \mathrm{~mol} \cdot \mathrm{m}^{-2} \cdot \mathrm{d}^{-1}$ for oregano, spearmint, and rosemary, and 14.8 and $10.8 \mathrm{~mol} \cdot \mathrm{m}^{-2} \cdot \mathrm{d}^{-1}$ for sage and thyme, respectively (Table 2, Fig. 2C and D). The stem caliper of yellow elder (Tecoma stans) seedlings after $35 \mathrm{~d}$ of propagation increased by $133 \%$ as the DLI increased from 0.8 to $25.2 \mathrm{~mol} \cdot \mathrm{m}^{-2} \cdot \mathrm{d}^{-1}$ (Torres and Lopez, 2011). Similarly, as the DLI increased from 2.0 to $13.4 \mathrm{~mol} \cdot \mathrm{m}^{-2} \cdot \mathrm{d}^{-1}$, the stem caliper of New Guinea impatiens increased by $26 \%$ after $14 \mathrm{~d}$ of treatments but did not influence the stem caliper of geranium or petunia (Currey and Lopez, 2015).

The trend of the SQ was like stem length for all culinary herbs, and generally decreased with increasing the DLI (Figs. 2E and $\mathrm{F}$ and $3 \mathrm{~A}$ ). This was expected because the
SQ is stem length divided by the stem caliper, and taller stems and smaller calipers were recorded under lower DLIs. In contrast, Currey et al. (2012) found the SQ of nemesia increased by $58 \%$ as DLI increased from 1.2 to $12.3 \mathrm{~mol} \cdot \mathrm{m}^{-2} \cdot \mathrm{d}^{-1}$ during propagation; while angelonia, diascia, lantana (Lantana camara), scaevola, sutera, and verbena (Verbena $\times$ hybrida) were unaffected by the DLI. Thyme SQ was influenced by the DLI more than other genera measured, decreasing by $53 \%$ as the DLI increased from 2.8 to 16.4 $\mathrm{mol} \cdot \mathrm{m}^{-2} \cdot \mathrm{d}^{-1}$ (Fig. 3A). This is largely due to the small stem caliper and upright habit of thyme; thus, the SQ may not be a good measurement to assess the quality of young culinary herbs.

Despite contrasting SQ results from the present study to previous studies, the QI of all culinary herbs showed similar results to other young plants. The QI is an integrative approach to assessing young plant quality by using the TDM, R:S, and SQ-with larger QIs being equivalent to high-quality plants (Currey et al., 2013). From this study, all culinary herb liners had high QIs at DLI optimums ranging from 10.4 to $16.4 \mathrm{~mol} \cdot \mathrm{m}^{-2} \cdot \mathrm{d}^{-1}$, dependent upon genus (Table 2, Figs. $2 \mathrm{G}$ and $\mathrm{H}$ and 3B). Currey et al. (2012) reported increasing QIs as the DLI increased from 1.2 to 12.3 $\mathrm{mol} \cdot \mathrm{m}^{-2} \cdot \mathrm{d}^{-1}$ for argyranthemum, diascia, nemesia, osteospermum, and sutera; whereas the QI of angelonia and lantana were greatest at DLIs of 10.6 and $7.2 \mathrm{~mol} \cdot \mathrm{m}^{-2} \cdot \mathrm{d}^{-1}$, respectively. Additionally, the QI of yellow elder increased by roughly 26 times as the DLI increased from 0.8 to $25.2 \mathrm{~mol} \cdot \mathrm{m}^{-2} \cdot \mathrm{d}^{-1}$ (Currey et al., 2013). Although the specific QI outlined in this study was not used, Fausey et al. (2005) used a quality rating on a scale of 1 (prostrate habit, poor lateral branching) to 5 (upright habit, extensive lateral branching) and found the quality of yarrow, wandflower (Gaura lindheimeri), and lavender increased from ratings between 2 to 3 to ratings between 4 to 5 as the DLI increased from 5 to $20 \mathrm{~mol} \cdot \mathrm{m}^{-2} \cdot \mathrm{d}^{-1}$. It is supported by our study and previous studies that the QI increases as the DLI increases, but to genus-specific DLI optimums.

Although not measured, the overall visible appearance of the culinary herb liners propagated under DLIs of 11.2 to 16.4 $\mathrm{mol} \cdot \mathrm{m}^{-2} \cdot \mathrm{d}^{-1}$ is worth mentioning. Liners of sage and spearmint developed small $(\leq 1 \mathrm{~mm})$ necrotic lesions on the adaxial surface of leaves; however, new growth from these liners, once transplanted into a common environment with a DLI of 17 and $12 \mathrm{~mol} \cdot \mathrm{m}^{-2} \cdot \mathrm{d}^{-1}$, respectively, were unaffected. Furthermore, from the collective results, the culinary herbs in this study can benefit from DLIs between 10 to $12 \mathrm{~mol} \cdot \mathrm{m}^{-2} \cdot \mathrm{d}^{-1}$ without sacrificing plant quality, and higher DLIs are not necessary as we previously hypothesized. This finding is crucial because culinary herbs are produced year-round, and some greenhouses (such as in northern latitudes) may not be able to supply enough supplemental lighting to achieve summer DLIs in late winter and early spring. Thus, achieving DLIs $>15 \mathrm{~mol} \cdot \mathrm{m}^{-2} \cdot \mathrm{d}^{-1}$ is not necessary to produce high-quality culinary herb liners, and unnecessary energy cost from supplemental lighting can be avoided.

\section{Conclusion}

For the herbs investigated, a DLI between 10 to $12 \mathrm{~mol} \cdot \mathrm{m}^{-2} \cdot \mathrm{d}^{-1}$ resulted in optimal values for most of the quality measurements recorded. Furthermore, the quality of oregano, rosemary, sage, spearmint, and thyme rooted cuttings under DLIs $\geq 16 \mathrm{~mol} \cdot \mathrm{m}^{-2} \cdot \mathrm{d}^{-1}$ were reduced due to genus-specific decreases in TDM, SQ, QI, and appearance of necrotic lesions. Lastly, we determined that rooting time of culinary herbs studied is shorter than most herbaceous ornamental cuttings: 2 weeks for oregano and spearmint, 3 weeks for sage and thyme, and at least 4 weeks for rosemary to produce a pullable liner. However, culinary herbs can be propagated under similar environmental conditions to ornamental cuttings.

\section{Literature Cited}

Currey, C.J. and R.G. Lopez. 2012. Biomass accumulation, allocation and leaf morphology of Impatiens hawkeri 'Magnum Salmon' cuttings is affected by photosynthetic daily light integral in propagation. Acta Hort. 956:349-355, doi: 10.17660/ActaHortic. 2012.956.40. 
Currey, C.J. and R.G. Lopez. 2015. Biomass accumulation and allocation, photosynthesis, and carbohydrate status of New Guinea impatiens, geranium, and petunia cuttings are affected by photosynthetic daily light integral during root development. J. Amer. Soc. Hort. Sci. 140(6):542-549, doi: 10.21273/ JASHS.140.6.542.

Currey, C.J., A.P. Torres, R.G. Lopez, and D.F. Jacobs. 2013. The quality index-A new tool for integrating quantitative measurements to assess quality of young floriculture plants. Acta Hort. 1000:385-391, doi: 10.17660/ActaHortic.2013.1000.53.

Currey, C.J., V.A. Hutchinson, and R.G. Lopez. 2012. Growth, morphology, and quality of rooted cuttings of several herbaceous annual bedding plants are influenced by photosynthetic daily light integral during root development. HortScience 47(1):25-30, doi: 10.21273/ HORTSCI.47.1.25.

Dole, J.M. and D.J. Hamrick. 2006. Propagation basics, p. 3-16. In: J.M. Dole and J.L. Gibson (eds.). Cutting propagation: A guide to propagating and producing floriculture crops. Ball Publishing, Batavia, IL.

Dou, H., G. Niu, M. Gu, and J.G. Masabni. 2018. Responses of sweet basil to different daily light integrals in photosynthesis, morphology, yield, and nutritional quality. HortScience 53(4):496-503, doi: 10.21273/ HORTSCI12785-17.

Fausey, B.A., R.D. Heins, and A.C. Cameron. 2005. Daily light integral affects flowering and quality of greenhouse-grown Achillea, Gaura, and Lavandula. HortScience 40(1):114-118, doi: 10.21273/HORTSCI.40.1.114.
Faust, J.E. 2011. Light, p. 83-94. In: J. Nau (ed.) Ball redbook: Crop production. Vol. 2. 18th ed. Ball Publishing, West Chicago, IL.

Faust, J.E., V. Holcombe, N.C. Rajapakse, and D.R. Layne. 2005. The effect of daily light integral on bedding plant growth and flowering. HortScience 40(3):645-649, doi: 10.21273/ HORTSCI.40.3.645.

Hutchinson, V.A., C.J. Currey, and R.G. Lopez. 2012. Photosynthetic daily light integral during root development influences subsequent growth and development of several herbaceous annual bedding plants. HortScience 47(7):856-860, doi: 10.21273/HORTSCI. 47.7.856.

Kaiser, C. and M. Ernst. 2020. Culinary herbs. CCD-CP-51. Center for Crop Diversification, University of Kentucky College of Agriculture, Food and Environment, Lexington. 9 Nov. 2020. <http://www.uky.edu/ccd/sites/www.uky.edu.ccd/files/herbs.pdf $>$.

Litvin-Zabal, A.G. 2019. Quantifying the effects of light quantity and quality on culinary herb physiology. Iowa State Univ., Ames, PhD Diss.

Lopez, R.G. and E.S. Runkle. 2008. Photosynthetic daily light integral during propagation influences rooting and growth of cuttings and subsequent development of new guinea impatiens and petunia. HortScience 43(7):2052-2059, doi: 10.21273/HORTSCI.43.7.2052.

Mapes, C. and Y. Xu. 2014. Photosynthesis, vegetative habit and culinary properties of sage (Salvia officinalis) in response to low-light conditions. Can. J. Plant Sci. 94(5):881-889, doi: 10.4141/cjps-2014-010.

Pramuk, L.A. and E.S. Runkle. 2005. Photosynthetic daily light integral during the seedling stage influences subsequent growth and flowering of Celosia, Impatiens, Salvia, Tagetes, and
Viola. HortScience 40(5):1336-1339, doi: 10.21273/HORTSCI.40.5.1336.

Raviv, M. and E. Putievsky. 1988. The propagation and production of dual-purpose potted aromatic plants. Acta Hort. 226:389-396, doi: 10.17660/ ActaHortic. 1988.226.48.

Torres, A.P. and R.G. Lopez. 2011. Photosynthetic daily light integral during propagation of Tecoma stans influences seedling rooting and growth. HortScience 46(2):282-286, doi: 10.21273/HORTSCI.46.2.282.

U.S. Department of Agriculture (USDA). 2010. Census of horticultural specialties (2009). Natl. Agr. Stat. Serv., Washington DC. 4 Apr. 2020. <https://www.nass.usda.gov/Publications/AgCensus/2007/Online_Highlights/ Census_of_Horticulture_Specialties/HORTIC. pdf $>$.

U.S. Department of Agriculture (USDA). 2020. Census of horticultural specialties (2019). Natl. Agr. Stat. Serv., Washington DC. 20 Dec. 2020. <https://www.nass.usda.gov/Publications/AgCensus/2017/Online_Resources/ Census_of_Horticulture_Specialties/index.php >.

UN COMTRADE. 2020. UN COMTRADE database. 6 Mar. 2020. <https://comtrade.un.org/ data $/>$.

Walters, K.J. 2020. Controlled environment production impacts hydroponically grown culinary herb physiology, biochemistry, and consumer preference. Michigan State Univ., East Lansing, $\mathrm{PhD}$ Diss.

Walters, K.J., B.K. Behe, C.J. Currey, and R.G. Lopez. 2020. Historical, current, and future perspectives for controlled environment hydroponic food crop production in the United States. HortScience 55(6):758-767, doi: 10.21273/HORTSCI14901-20. 